DOI: https://doi.org/10.24127/ajpm.v9i3.3027

\title{
GAME ANDROID "MENALAR" BERBASIS ADOBE ANIMATION CC
}

\author{
Ryan Angga Pratama ${ }^{1}$, Rahayu Sri Waskitoningtyas ${ }^{2}$ \\ ${ }^{1,2}$ Pendidikan Matematika Universitas Balikpapan, Indonesia \\ *Corresponding author. Jl. Manggar Indah RT 31 No 189 Balikpapan Timur, 76116, Indonesia \\ E-mail: $\quad$ ryan.angga@uniba-bpn.ac.id ${ }^{\left.{ }^{*}\right)}$ \\ rahayu.sri@uniba-bpn.ac.id $^{2}$
}

Received 10 August 2020; Received in revised form 11 September 2020; Accepted 26 September 220

\begin{abstract}
Abstrak
Penelitian ini bertujuan untuk menghasilkan media pembelajaran jarak jauh dengan menggunakan Adobe Animation CC yaitu berupa permainan edukasi "MENALAR" yang dapat dimainkan di ponsel cerdas. Produk dikembangkan dengan memperhatikan aspek validitas, kepraktisan, dan keefektifan dalam pembelajaran matematika pada siswa kelas X SMA Negeri 5 Balikpapan. Adapun implementasinya menggunakan desain pengembangan Multimedia Development Life Cycle (MDLC) yang terdiri dari: konsep, perancangan, pengumpulan materi, pembuatan, pengujian, dan distribusi. Hasil tersebut diperoleh dari pengujian media yang terdiri dari uji Alpha dan uji Beta dalam kelompok kecil, dan uji Beta dalam kelompok besar. Hasil penelitian menyimpulkan bahwa game edukasi "MENALAR" berbasis Adobe Animation CC termasuk dalam kategori sangat valid dengan persentase $88,9 \%$, sangat praktis dengan persentase rata-rata $83,6 \%$; dan efektif meskipun persentase ketuntasan hanya mencapai $60,4 \%$. Sehingga secara keseluruhan media pembelajaran yang dikembangkan dapat menjadi alternatif dalam kegiatan pembelajaran khususnya mengenai soal-soal penalaran metematika.
\end{abstract}

Kata kunci: Adobe Animation CC; game android; MENALAR.

\begin{abstract}
This study aims to produce distance learning media using Adobe Animation CC, which is a "MENALAR" educational game that can be played on a smartphone (Android). The product is developed by attention to the aspects of validity, practicality, and effectiveness in learning mathematics in X-Grade Students of SMA Negeri 5 Balikpapan. The implementation uses Multimedia Development Life Cycle (MDLC) design consisting of: concept, design, material collection, assembly, testing, and distribution. These results were obtained from media testing consisting of Alpha and Beta test (in small and large groups). The results of the study concluded that the educational game "MENALAR" based on Adobe Animation $C C$ was included in the very valid with an average percentage of $88,9 \%$, very practical with an average percentage of 83,6\%; and effective even though the percentage of completeness only reaches $60,4 \%$. So that overall the learning media developed can be an alternative in learning activities, especially mathematics reasoning problems.
\end{abstract}

Keywords:Adobe Animation CC; android game; MENALAR.

This is an open access article under the Creative Commons Attribution 4.0 International License

\section{PENDAHULUAN}

Andorid merupakan sistem operasi yang sudah tidak asing lagi di kalangan siswa SMA (Lubis \& Ikhsan, 2015). Namun, penggunaan ponsel cerdas dengan sistem operasi tersebut saat ini lebih banyak digunakan sebagai sarana hiburan dibandingkan untuk pendidikan. Di sisi lain, pengguna sistem operasi Android yang begitu banyak di kalangan remaja siswa SMA menjadikan peluang bagi guru untuk mengembangkan media pembelajaran berbasis Android. Pemanfaatan media pembelajaran berbasis Android sebisa mungkin dapat diterapkan di semua 
DOI: https://doi.org/10.24127/ajpm.v9i3.3027

mata pelajaran, termasuk matematika (Larasati, Pratama, \& Khotimah, 2019).

Matematika merupakan pelajaran yang sangat penting dalam kehidupan manusia karena matematika berperan hampir di seluruh aspek kehidupan (Siregar, 2017; Sholihah \& Mahmudi, 2015), bahkan di era digital seperti saat ini. Oleh karena itu, matematika menjadi mata pelajaran yang diberikan di semua jenjang sebagai bekal siswa untuk memiliki kemampuan berpikir logis, analitis, sistematis, kritis, dan kreatif. Selain itu, matematika perlu diberikan untuk membekali siswa dengan kemampuan berpikir nalar.

Dalam belajar matematika siswa dituntut untuk memiliki kemampuan: komunikasi matematis, penalaran matematis, pemecahan masalah matematis, koneksi matematis, dan representasi matematis (NCTM, 2000). Berdasarkan hal tersebut, penalaran merupakan salah satu aspek dari kemampuan berpikir matematika tingkat tinggi yang harus dikuasai siswa (Mikrayanti, 2016; Somatanaya, 2017). Sebagaimana diketahui, proses pembelajaran pada Kurikulum 2013 untuk semua jenjang pendidikan baik SD, SMP/MTs maupun SMA/MA/SMK/MAK dilaksanakan dengan menggunakan pendekatan saintifik yang meliputi pengamatan, bertanya, percobaan, mengolah informasi, menyajikan data, menganalisis, menalar, menyimpulkan dan mencipta, serta mengomunikasikan (Setiawan, 2018). Dari sini jelas bahwa kemampuan penalaran matematis juga merupakan aspek yang sangat penting dan esensial. Shadiq (2004) menyatakan bahwa selama mempelajari matematika di kelas, aplikasi penalaran sering ditemukan meskipun tidak secara formal disebut sebagai belajar bernalar. Menyadari pentingnya penalaran matematika dalam stuktur pembelajaran di kurikulum saat ini maka diperlukan pembelajaran yang dapat meningkatkan penalaran matematika siswa. Salah satu cara yang dapat digunakan untuk meningkatkan kemampuan penalaran dan komunikasi matematika siswa adalah dengan menggunakan media pembelajaran secara efektif dan efisien.

Pentingnya peranan matematika dalam kehidupan ternyata tidak didukung dengan fakta yang terjadi di lapangan. Berdasarkan observasi awal yang dilakukan di kelas $\mathrm{X}$ SMK Kesehatan Airlangga Balikpapan jurusan Keperawatan pada tanggal 26 Februari 2019 ditemukan bahwa proses pembelajaran guru sudah bervariatif menggunakan media pembelajaran $M s$. PowerPoint. Namun, guru kurang mengajak siswa untuk berpikir kritis. Hal ini tampak dari contoh-contoh soal penalaran di buku teks jarang dibahas sehingga membuat siswa tidak terbiasa untuk kritis dan mengkonstruksi pengetahuan sendiri. Sebagaimana pendapat Setiawan (2018), pembelajaran matematika yang kurang memberikan kesempatan siswa untuk terlibat di dalamnya akan mengakibatkan rendahnya penalaran siswa. Lebih lanjut, dari hasil wawancara terhadap guru di sekolah lainnya, yakni di SMA Negeri 5 Balikpapan, bahwa penggunaan teknologi informasi dan komunikasi dalam proses pembelajaran matematika, guru lebih sering meminta siswa untuk belajar dengan memanfaatkan $e$ learning, pencarian di Google, serta menonton YouTube. Hal ini sangat mendukung siswa untuk belajar mandiri dan mengkonsturksi pengetahuannya sendiri, namun juga berpotensi disalahgunakan siswa untuk sekadar bermain saja. Misalnya saja, siswa cenderung asyik sendiri dalam proses 
pembelajaran atau memainkan ponsel cerdasnya saat guru sedang menjelaskan. Untuk itu, perlu dikembangkan media pembelajaran yang dapat mengatasi hal tersebut.

Media pembelajaran merupakan alat bantu yang digunakan oleh guru untuk menyampaikan atau menyalurkan pesan (materi pelajaran) kepada siswa (Asyhar, 2012; Rusman, 2012), sekaligus sebagai alat untuk merangsang pikiran, perasaan, perhatian dan minat siswa untuk belajar, dalam rangka mencapai tujuan pendidikan (Sanjaya, 2012). Selanjutnya, menurut Arsyad (2011), penggunaan media pembelajaran dalam proses belajar mengajar dapat membangkitkan keinginan dan minat yang baru, membangkitkan motivasi dan rangsangan kegiatan belajar, membantu siswa meningkatkan pemahaman, menyajikan data secara menarik dan terpercaya, memudahkan penafsiran data, dan memadatkan informasi. Rusman (2012) pun menambahkan bahwa media pembelajaran dapat pula menjadikan materi pembelajaran lebih jelas maknanya sehingga dapat lebih dipahami oleh para siswa, metode pembelajaran akan lebih bervariasi, serta siswa lebih banyak melakukan kegiatan belajar. Terlebih di masa pandemi Covid-19 saat ini, di mana pembelajaran cenderung dilakukan secara jarak jauh. Sebagian besar sekolah (guru pada khususnya) melaksanakan kegiatan pembelajarannya menggunakan Google Classroom. Namun, konten materi penyajiannya masih menggunakan $M s$. PowerPoint, modul materi dari PDF ataupun Ms. Word. Guru belum banyak menggunakan game edukasi untuk pembelajarannya.

Sebagaimana diketahui, kemajuan teknologi yang pesat menyebabkan proses pembelajaran berbasis teknologi informasi dapat dilakukan dengan menggunakan komputer (Aini, Ayu, \& Siswati, 2019), ataupun perangkat lain seperti ponsel cerdas. Perkembangan ponsel cerdas tidak hanya sebatas sebagai alat komunikasi, namun saat ini telah banyak digunakan sebagai media pembelajaran (Ismanto, Novalia, \& Herlandy, 2017). Perkembangan tersebut memunculkan istilah baru dalam pembelajaran yang disebut sebagai mobile learning (M-learning) (Muhson, 2010; Rasyid, Gaffar, \& Utari, 2020). Media pembelajaran pada perangkat Android menjadi salah satu alternatif baru dalam pembelajaran yang menarik dan menyenangkan (Ismanto, Novalia, \& Herlandy, 2017). Selain itu, media pembelajaran berbasis Android juga memiliki kelebihan yaitu mudah digunakan, menarik, belajar bisa di mana saja, serta belajar secara offline atau tidak terhubung ke internet (Kuswanto \& Radiansah, 2018).

Salah satu media pembelajaran berbasis android yang seringkali digunakan adalah game. Game edukasi merupakan permainan atau aktivitas menyenangkan yang memuat konten pendidikan (Sari, Saputro, \& Hastuti 2014; Festus \& Adeyeye, 2012). Pengertian lainnya, game edukasi merupakan kombinasi antara pendidikan dengan hiburan yang dibuat untuk merangsang daya pikir termasuk meningkatkan konsentrasi dan memecahkan masalah (Panagiotakopoulos, 2011). Adapun tujuan digunakannya game dalam pembelajaran untuk memancing minat belajar siswa terhadap materi pelajaran sambil bermain (Sari, Saputro, \& Hastuti, 2014), di mana mereka akan merasa senang dalam belajar matematika sambil bermain (Panagiotakopoulos, 2011). 
DOI: https://doi.org/10.24127/ajpm.v9i3.3027

Kajian penelitian terkait game edukasi pun menunjukkan hasil yang positif. Diketahui bahwa game edukasi memberikan keleluasaan bagi siswa untuk bereksplorasi, memfokuskan perintah dalam pembelajaran, konsep, dan pemecahan masalah (SERIN, 2011). Selain itu, game edukasi juga berpengaruh pada peningkatan performa akademik siswa SMA dan efektif pada hasil belajar siswa (Yektyastuti \& Ikhsan, 2016; Muyaroah \& Fajartia, 2017; Suprianto, Ahmadi, \& Suminar, 2019). Dengan demikian, jelas bahwa pemanfaatan game dalam dunia pendidikan merupakan suatu bentuk pembaharuan, dimana akan memberikan berbagai dampak yang positif dalam proses pembelajaran.

Melihat berpotensinya penggunaan teknologi informasi dan komunikasi dalam pembelajaran di era digital saat ini dan betapa pentingnya kemampuan penalaran siswa, maka perlu dilakukan suatu pengembangan produk media pembelajaran yang dapat dimanfaatkan untuk mendukung kegiatan pembelajaran dan penalaran siswa. Adapun produk tersebut berupa game edukasi berbasis Adobe Animation CC yang diberi nama "MENALAR".

Adobe Animation CC merupakan perangkat lunak komputer yang didesain oleh Adobe System. Perangkat lunak ini digunakan untuk membuat beragam jenis proyek termasuk animasi, media interaktif, game, aplikasi ponsel cerdas, dan lain sebagainya (Wibawanto, 2017). Pengembangan media pembelajaran ini sangat penting; terutama menerapkannya dalam pembelajaran di kondisi saat ini. Dengan menggunakan game edukasi, siswa akan dapat belajar secara mandiri, bertanggung jawab, dan diharapkan dapat meningkatkan hasil belajar ataupun penalaran matematika mereka.

\section{METODE PENELITIAN}

Penelitian ini merupakan penelitian dan pengembangan yang digunakan untuk menghasilkan produk dan menguji keefektifan produk tersebut (Sugiyono, 2017). Model pengembangannya menggunakan Multimedia Development Life Cycle (MDLC) versi Luther yang dikembangkan Sutopo (2009).

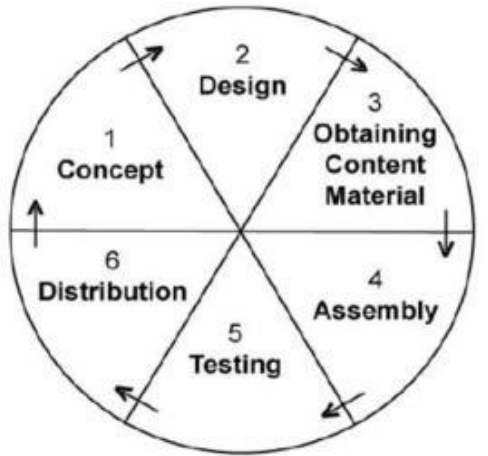

Gambar 1. Siklus Pengembangan MDLC (Sutopo, 2009; Nurajizah, 2016)

Berikut tahapan yang dilakukan.

1. Konsep (Concept)

Konsep dan tujuan pembuatan aplikasi adalah membantu siswa dalam pembelajaran matematika khususnya mengenai Penalaran Matematika Kelas X.

2. Perancangan (Design)

Tahapan ini menggunakan storyboard untuk menggambarkan rangkaian cerita/deskripsi tiap scene sehingga dapat dimengerti oleh pengguna, dengan mencantumkan semua objek multimedia dan tautan ke scene lain.

3. Pengumpulan Bahan (Obtaining Content Material)

Bahan yang dibutuhkan antara lain: gambar, animasi, audio, serta teks; baik yang sudah jadi ataupun yang masih perlu dimodifikasi sesuai dengan kebutuhan. 
DOI: https://doi.org/10.24127/ajpm.v9i3.3027

4. Pembuatan (Assembly)

Aplikasi yang dibuat didasarkan pada tahap perancangan. Tahap pembuatan aplikasi menggunakan perangkat lunak Adobe Animation CC.

5. Pengujian (Testing)

Ada dua jenis pengujian yang digunakan, yaitu pengujian Alpha dan Beta. Uji Alpha dilakukan oleh satu orang ahli media (guru berprestasi membuat media pembelajaran tahun 2019 kota Balikpapan), dua orang ahli materi (dosen pendidikan matematika Universitas Balikpapan dan guru matematika SMA Negeri 5 Balikpapan), serta dua praktisi pembelajaran (dosen pendidikan matematika Universitas Balikpapan dan guru matematika SMA Negeri 5 Balikpapan). Sedangkan uji Beta adalah pengujian yang dilakukan oleh pengguna sebanyak dua kali, yakni uji coba kecil dan besar. Untuk uji coba kecil, subjeknya adalah 9 siswa kelas X-IPA-2, sedangkan uji coba besar, subjeknya adalah 43 siswa dari perwakilan kelas X-IPA-1, X-IPA-4, dan X-IPS-1 SMAN 5 Balikpapan.

6. Distribusi (Distribution)

Aplikasi disimpan dan didistribusi melalui ponsel cerdas berupa paket aplikasi (.apk).

Pengumpulan data dilakukan dengan dokumentasi, tes, dan kuesioner. Adapun instrumen pengumpulan datanya sebagai berikut:

1. Dokumentasi

Dokumentasi berbentuk foto atau tangkapan layar selama penelitian.

2. Tes

Tes berupa soal penalaran pada materi Kelas X, yakni: persamaan dan pertidaksamaan linear satu variabel, sistem persamaan linear tiga variabel, sistem pertidaksamaan linear dua variabel, fungsi, dan trigonometri.

3. Kueisoner

a. Kuesioner untuk ahli media; berisi penilaian berdasarkan aspek audio, rekayasa perangkat lunak, dan tampilan visual.

b. Kuesioner untuk ahli materi; berisi penilaian berdasarkan aspek kualitas soal latihan bernalar, dan efek bagi strategi pembelajaran.

c. Kuesioner untuk praktisi/guru dan siswa; berisi penilaian berdasarkan aspek kualitas isi soal penalaran, efek bagi strategi pembelajaran, dan aspek rekayasa perangkat lunak.

Selanjutnya, skala Likert digunakan sebagai acuan dalam penyusunan angket. Skala Likert tersedia lima pilihan jawaban dengan format: Sangat Tidak Setuju (STS) $=1$; Tidak Setuju $(\mathrm{TS})=2$; Ragu $(\mathrm{R})=3$; Setuju $(\mathrm{S})=4$; dan Sangat Setuju (SS) = 5 (Sugiyono, 2017).

Selanjutnya, analisis data yang dilakukan adalah menganalisis validitas, kepraktisan, dan keefektifan media pembelajaran yang dikembangkan. Berikut penjelasannya:

1. Analisis Validitas dan Kepraktisan

Rumus (1) yang digunakan sebagai berikut.

$$
P=\frac{T S h}{T S e} \times 100 \%
$$

Keterangan:

$P$ : Persentase validitas/kepraktisan

TSh : Total skor harapan

TSe : Total skor empiris

(Rozak, Darmadi, \& Murtafi'ah, 2018).

Hasil dari perhitungan adalah berupa persentase kevalidas. Kemudian dari hasil yang diperoleh dari proses perhitungan dan analisis kemudian diinterpretasikan kedalam kategaori 
DOI: https://doi.org/10.24127/ajpm.v9i3.3027

yang sesuai. Dasar dari interpretasi hasil atau skor validasi dapat dilihat pada Tabel 1.

Tabel 1. Kriteria Validitas/Kepraktisan

\begin{tabular}{cc}
\hline Penilaian (\%) & Kategori \\
\hline $80 \leq P \leq 100$ & Sangat Valid/Sangat Praktis \\
$60 \leq P<80$ & Valid/Praktis \\
$40 \leq P<60$ & Cukup Valid/Cukup Praktis \\
$20 \leq P<40$ & Kurang Valid/Kurang Praktis \\
$0 \leq P<20$ & Sangat Kurang Valid/Sangat \\
& Kurang Praktis \\
\hline
\end{tabular}

(Dasmo, Astuti, \& Nurullaeli, 2017)

\section{Analisis Keefektifan}

Analisis terhadap keefektifan game edukasi "MENALAR" dilakukan terhadap hasil tes penalaran siswa. Data kemudian dianalisis dengan menghitung banyaknya siswa yang mampu mencapai Kriteria Ketuntasan Minimal (KKM) yang telah ditentukan oleh pihak sekolah yakni nilai 73 dari nilai maksimal 100. Data tersebut kemudian diinterpretasikan ke dalam kriteria keefektifan dengan acuan sebagai berikut.

Tabel 2. Kriteria Keefektifan

\begin{tabular}{cc}
\hline Persentase (\%) & Kategori \\
\hline$p>80$ & Sangat Efektif \\
$60<p \leq 80$ & Efektif \\
$40<p \leq 60$ & Cukup Efektif \\
$20<p \leq 40$ & Kurang Efektif \\
$p \leq 20$ & Sangat Kurang Efektif \\
\hline
\end{tabular}

(Yuliana, 2017)

Keterangan :

$p$ : Persentase banyaknya siswa yang mencapai nilai di atas KKM
Berdasarkan Tabel 2, game edukasi "MENALAR" dapat dikatakan efektif apabila persentase banyaknya siswa yang mencapai nilai di atas atau sama dengan KKM, yakni lebih dari $60 \%$ dari jumlah keseluruhan siswa yang telah memainkan game tersebut.

\section{HASIL DAN PEMBAHASAN}

Hasil penelitian dan pengembangan yang diperoleh dengan menggunakan metode pengembangan Multimedia Development Life Cycle (MDLC) dijabarkan sebagai berikut:

1. Konsep (Concept)

Konsep dan tujuan pembuatan aplikasi adalah membantu siswa dalam pembelajaran matematika khususnya mengenai soal-soal penalaran. Konsep sajian game edukasi berupa latihan soalsoal penalaran sebanyak 15 butir dengan dibatasi waktu maksimal masing-masing soal adalah 5 menit. Pada bagian akhir juga diberikan pembahasan dari masing-masing soal.

2. Perancangan (Design)

Pada tahap ini dilakukan perancangan materi dan pembuatan stroyboard untuk menggambarkan tahapan dari tiap scene.

\section{Pengumpulan Bahan (Obtaining Content Material)}

Bahan yang dibutuhkan antara lain: soal-soal penalaran dari beberapa buku teks, gambar, animasi, audio, serta teks. Adapun peralatan dan perlengkapan yang digunakan adalah laptop, USB flashdisk, internet, serta aplikasi Adobe Animation CC.

\section{Pembuatan (Assembly)}

Beberapa tampilan akhir produk game edukasi "MENALAR" yang dapat dilihat pada Gambar 2 sampai 7. 


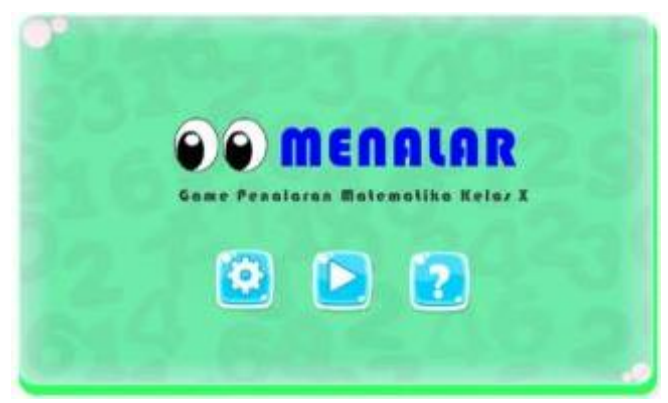

Gambar 2. Tampilan awal.

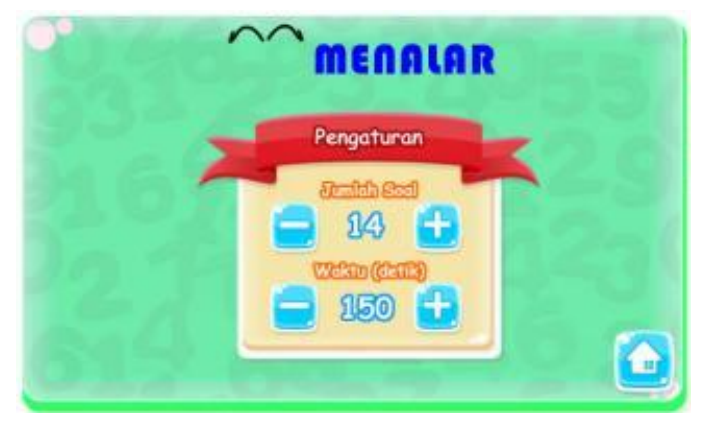

Gambar 3. Pengaturan soal dan waktu.

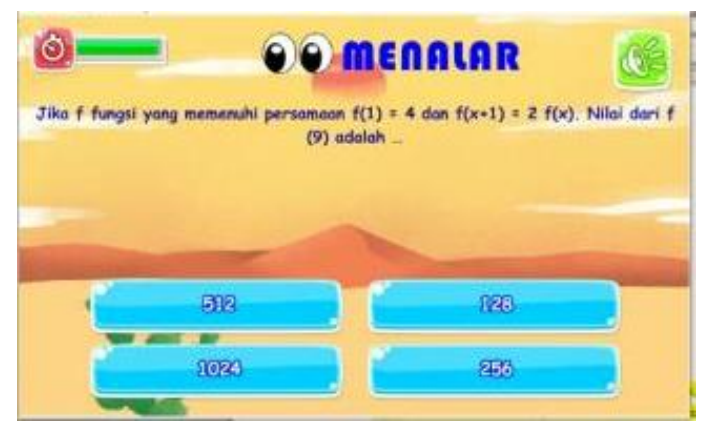

Gambar 4. Contoh tampilan soal penalaran dengan dibatasi waktu.

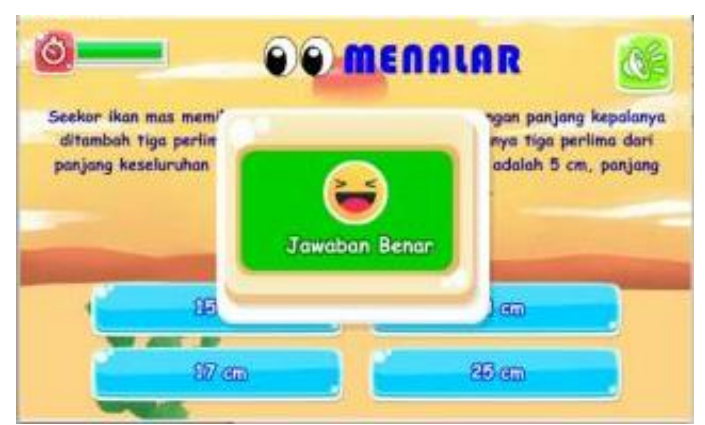

Gambar 5. Pop-up jawaban benar

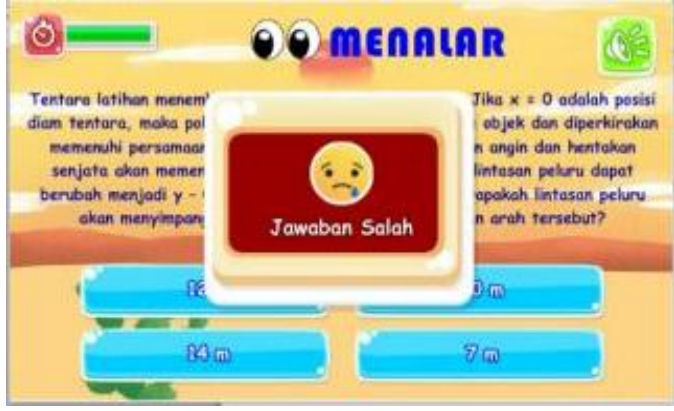

Gambar 6. Pop-Up Jawaban Salah

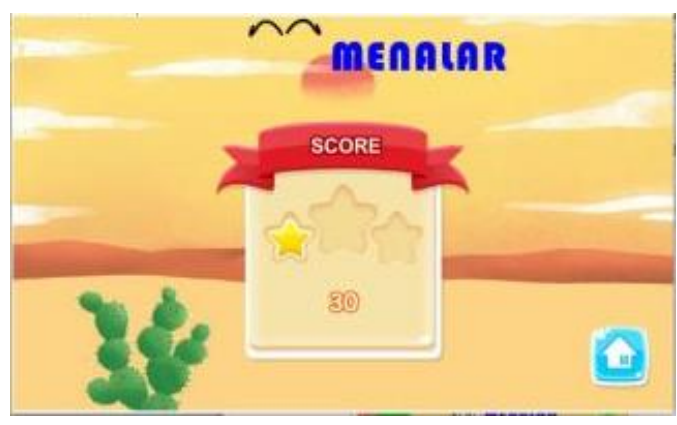

Gambar 7. Tampilan Skor di Akhir Soal

\section{Pengujian (Testing)}

Pengujian dilakukan untuk menguji game edukasi "MENALAR" dari segi validitas, kepraktisan, dan juga keefektifan. Proses awal dalam pengujian ialah dilakukannya uji Alpha. Uji Alpha dilakukan dalam satu tahap untuk mengetahui kelayakan suatu media pembelajaran yang divalidasi oleh satu orang ahli media, dua orang ahli materi dan evaluasi pembelajaran, dan juga dua orang praktisi pembelajaran. Dikarenakan kondisi Pandemi Covid-19, maka segala pelaksanaan uji coba dilakukan secara jarak jauh.

\section{a. Uji Alpha}

Ahli media mengisi angket validasi melalui tautan: http://bit.ly/AngketAhliMedia. Hasil penilaian dari ahli media dapat dilihat pada Tabel 3. Secara umum, 
DOI: https://doi.org/10.24127/ajpm.v9i3.3027

berdasarkan hasil dari uji Alpha dengan Ahli media, komentar yang diberikan positif dan hasil atau skor yang diberikan juga baik dan positif. Berikut hasil komentarnya: "Game Menalar sangat menarik dan dapat membantu guru dalam pembelajaran individual berbasis IT. Selain itu, game mudah dioperasikan karena dilengkapi dengan petunjuk penggunaan."

Tabel 3. Hasil penilaian ahli media pada uji Alpha.

\begin{tabular}{lc}
\hline \multirow{1}{*}{ Indikator } & Alpha \\
\cline { 2 - 2 } & Skor Ahli 1 \\
\hline Efek suara & 5 \\
Backsound & 5 \\
Komposisi warna & 5 \\
Jenis font & 5 \\
Ukuran font & 5 \\
Tampilan teks & 5 \\
Penempatan gambar/objek & 5 \\
Proporsi gambar/objek & 5 \\
Desain tampilan & 5 \\
Fungsi touch & 5 \\
Alur game & 5 \\
Kemudahan pengoperasian & 5 \\
Kemudahan pengelolaan & 5 \\
\hline Total & 65 \\
\hline Persentase & Sangat Valid \\
\hline Kriteria & $100 \%$ \\
\hline
\end{tabular}

Adapun kekurangan game edukasi "MENALAR" diantaranya dari aspek kelengkapan isi dan fungsi tombol. Berikut hasil komentarnya: sebaiknya game dilengkapi dengan pembahasan kunci jawaban khususnya pada soal yang dijawab salah oleh pengguna, serta bisa ditambahkan kalimat motivasi untuk pengguna. Oleh karena itu, perlu direvisi sebelum diujicobakan kepada siswa. Selain itu, game edukasi "MENALAR" juga divalidasi oleh ahli materi \& evaluasi pembelajaran.
Mereka mengisi melalui tautan: http://bit.ly/AngketAhliMateri. hasil dari penilaian ahli materi dan evaluasi pembelajaran pada uji Alpha dapat dilihat pada Tabel 4.

Tabel 4. Hasil penilaian ahli materi dan evaluasi pembelajaran pada uji Alpha

\begin{tabular}{|c|c|c|}
\hline \multirow[b]{2}{*}{ Indikator } & \multicolumn{2}{|c|}{ Alpha } \\
\hline & $\begin{array}{c}\text { Skor } \\
\text { Ahli } 1\end{array}$ & $\begin{array}{c}\text { Skor } \\
\text { Ahli } 2\end{array}$ \\
\hline $\begin{array}{l}\text { Kesesuaian dengan buku } \\
\text { teks }\end{array}$ & 4 & 5 \\
\hline Kesesuaian KD & 4 & 5 \\
\hline $\begin{array}{l}\text { Kelengkapan soal } \\
\text { penalaran }\end{array}$ & 4 & 4 \\
\hline Sistematis/keberurutan & 4 & 5 \\
\hline $\begin{array}{l}\text { Kejelasan sajian materi } \\
\text { pembahasan }\end{array}$ & 4 & 4 \\
\hline $\begin{array}{l}\text { Kejelasan sajian soal } \\
\text { penalaran }\end{array}$ & 3 & 3 \\
\hline $\begin{array}{l}\text { Soal sesuai dengan buku } \\
\text { teks }\end{array}$ & 4 & 5 \\
\hline Kejelasan tampilan soal & 4 & 5 \\
\hline $\begin{array}{l}\text { Kebenaran pembahasan } \\
\text { soal }\end{array}$ & 4 & 3 \\
\hline $\begin{array}{l}\text { Kesesuaian tingkat } \\
\text { kesulitan }\end{array}$ & 4 & 4 \\
\hline $\begin{array}{l}\text { Kebermanfaatan dalam } \\
\text { motivasi belajar }\end{array}$ & 5 & 5 \\
\hline $\begin{array}{l}\text { Kemudahan belajar } \\
\text { mandiri }\end{array}$ & 4 & 5 \\
\hline Kebermanfaatan bernalar & 5 & 5 \\
\hline Total & 53 & 58 \\
\hline Persentase & $81,5 \%$ & $89,2 \%$ \\
\hline Kriteria & $\begin{array}{c}\text { Sangat } \\
\text { Valid }\end{array}$ & $\begin{array}{l}\text { Sangat } \\
\text { Valid }\end{array}$ \\
\hline
\end{tabular}

Secara umum, berdasarkan hasil analisis angket dari kedua ahli materi pada uji Alpha, diperoleh komentar yang mengharuskan adanya revisi sebelum diujicobakan kepada siswa. 
DOI: https://doi.org/10.24127/ajpm.v9i3.3027

Tabel 5. Hasil penilaian praktisi pembelajaran uji Alpha.

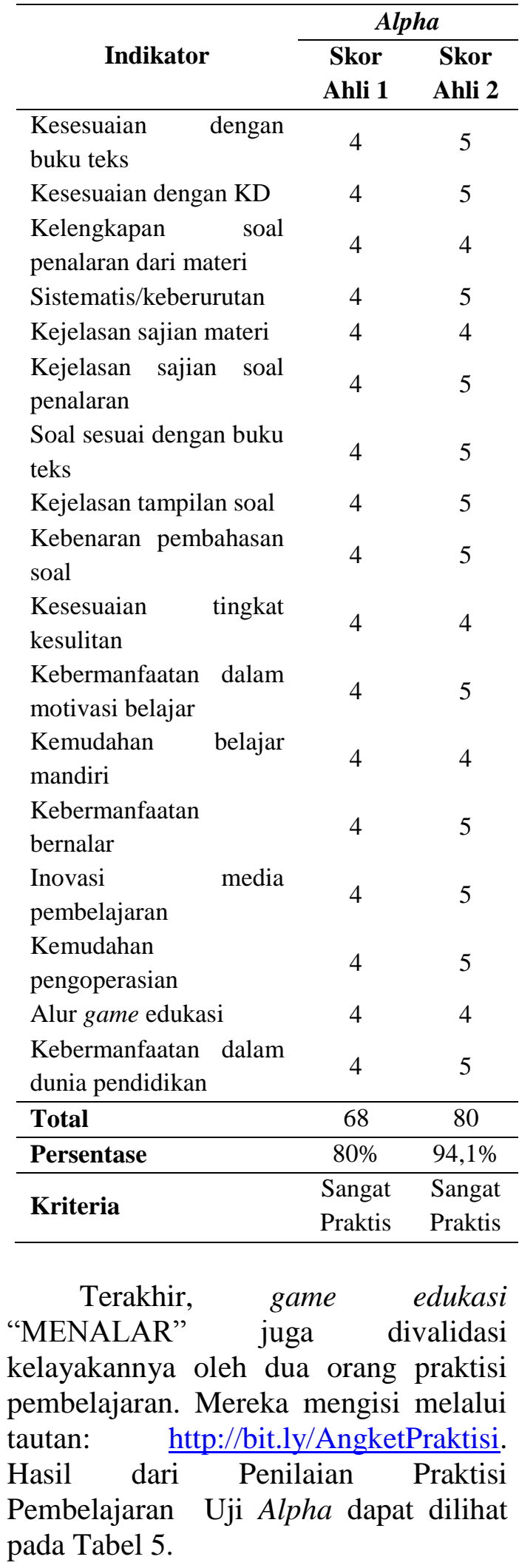

Berdasarkan Tabel 5, secara menyeluruh game edukasi "MENALAR" mendapatkan respon yang positif. Berikut hasil komentarnya: game-nya bagus dan ke depannya bisa digunakan untuk semua jenis HP (Android dan Iphone), serta perlunya ditulis langkah-langkah pembahasan soal.

Secara menyeluruh dari hasil data anlisis uji Alpha yang telah dipaparkan maka dapat dilihat penilaian terhadap game edukasi "MENALAR" yang dilakukan oleh lima orang ahli adalah sebesar 88,9\% (termasuk dalam kategori sangat valid). Selanjutnya, para ahli akan memberikan saran dan rekomendasi apabila media dirasa belum layak agar dilakukan revisi. Setelah direvisi, selanjutnya pengujian Beta dilakukan untuk melihat kepratisan dari game edukasi "MENALAR" yang dikembangkan. Uji Beta dilakukan dalam dua tahap, yaitu uji kelompok kecil dan uji kelompok besar.

\section{b. Uji Beta}

Uji Beta kelompok kecil dilaksanakan pada tanggal 28 April 2020 terhadap 9 subjek siswa kelas XIPA-2 SMAN 5 Balikpapan. Sedangkan uji Beta kelompok besar dilaksanakan pada tanggal 1 Mei 2020 terhadap 21 siswa X-IPA-1, 8 siswa X-IPA-4, dan 14 siswa X-IPS-1 SMAN 5 Balikpapan. Uji Beta dilakukan sebagai uji lanjutan dari uji Alpha dengan tujuan untuk melihat efektifitas dari media. Hasil dari uji Beta dapat dilihat pada Tabel 6.

Berdasarkan data analisis uji Beta yang telah dipaparkan pada Tabel 6, maka dapat dilihat penilaian secara keseluruhan terhadap game edukasi "MENALAR" yang dilakukan termasuk dalam kategori Praktis untuk digunakan dalam proses kegiatan 
DOI: https://doi.org/10.24127/ajpm.v9i3.3027

pembelajaran. Siswa pun memberikan tanggapan positif. Berikut diantaranya:

1) Aplikasi menarik, menyenangkan, dan sangat membantu

2) Latihan soalnya mudah dipahami

3) Aplikasinya membantu saya untuk belajar mandiri

Namun beberapa diantaranya memberikan komentar atau saran:

1) Waktunya tolong diperpanjang

2) Lagu atau backsound-nya jangan terlalu tegang-tegang

Tabel 6. Hasil penilaian uji Beta.

\begin{tabular}{|c|c|c|}
\hline Indikator & $\begin{array}{c}\text { Kecil } \\
\text { Skor } 9 \\
\text { Siswa } \\
\end{array}$ & $\begin{array}{c}\text { Besar } \\
\text { Skor } 43 \\
\text { Siswa } \\
\end{array}$ \\
\hline Tampilan menarik & 34 & 176 \\
\hline Efek suara menarik & 30 & 162 \\
\hline Kemudahan fungsi touch & 36 & 186 \\
\hline Alur game edukasi & 30 & 165 \\
\hline $\begin{array}{l}\text { Kemudahan dalam } \\
\text { permainan }\end{array}$ & 34 & 171 \\
\hline $\begin{array}{l}\text { Kejelasan sajian soal } \\
\text { penalaran }\end{array}$ & 36 & 173 \\
\hline $\begin{array}{l}\text { Kelengkapan sajian soal } \\
\text { penalaran }\end{array}$ & 35 & 177 \\
\hline $\begin{array}{lr}\text { Kelengkapan } & \text { sajian } \\
\text { pembahasan } & \text { soal } \\
\text { penelaaran } & \end{array}$ & 36 & 178 \\
\hline $\begin{array}{l}\text { Kesesuaian soal dengan } \\
\text { kemampuan siswa }\end{array}$ & 32 & 157 \\
\hline $\begin{array}{l}\text { Pembelajaran variatif } \\
\text { dan menyenangkan }\end{array}$ & 32 & 172 \\
\hline $\begin{array}{l}\text { Kemudahan dan motivasi } \\
\text { belajar mandiri }\end{array}$ & 33 & 170 \\
\hline $\begin{array}{l}\text { Kebermanfaatan } \\
\text { pengetahuan }\end{array}$ & 33 & 172 \\
\hline $\begin{array}{l}\text { Kebermanfaatan } \\
\text { penalaran }\end{array}$ & 33 & 174 \\
\hline Total & 433 & 2233 \\
\hline Persentase & $74 \%$ & $79,9 \%$ \\
\hline Kriteria & Praktis & Praktis \\
\hline
\end{tabular}

3) Sebaiknya diberikan tombol "Pause"

Secara menyeluruh dari hasil data anlisis uji Alpha dan Beta yang telah dipaparkan, maka dapat dilihat penilaian terhadap game edukasi
"MENALAR" yang dilakukan oleh dua orang Praktisi dan seluruh siswa pada uji Beta adalah sebesar 83,6\% (termasuk dalam kategori sangat praktis).

\section{Distribusi (Distribution)}

Aplikasi disimpan dan didistribusi melalui perangkat ponsel cerdas berupa file paket aplikasi (.apk). Adapun pendistribusian menggunakan tautan berikut:

http://bit.ly/UnduhGameMENALAR.

Pada saat pelaksanaan uji coba, secara teknis guru matematika menyebarkan game edukasi "MENALAR" melalui tautan http://bit.ly/UnduhGameMENALAR.

Pelaksanaan penelitian juga dikontrol secara jarak jauh melalui WhatsApp guru. Berdasarkan laporan guru, diketahui bahwa siswa/i mereka sangat antusias dengan game yang diberikan. Guru tersebut juga meminta siswa untuk mengumpulkan hasil perhitungan mereka dengan cara difoto.

Meskipun tidak dilakukan observasi secara langsung dikarenakan kondisi pandemi Covid-19, namun siswa tetap rajin belajar di rumah dan menyelesaikan soal-soal penalaran yang diberikan di game edukasi "MENALAR". Dengan memainkan game edukasi "MENALAR", diharapkan siswa dapat antusias dalam "belajar sambil bermain" menggunakan ponsel cerdas masing-masing. Mereka sangat berminat sekali dan memberikan tanggapan yang positif dari angket online yang diberikan melalui tautan http://bit.ly/AngketSiswaMENALAR.

Secara menyeluruh, hasil belajar siswa pada uji Beta (kelompok besar) mendapatkan hasil yang cukup baik, yakni rata-rata 68,6 di mana 26 dari 43 siswa mendapat nilai lebih dari 60 (sebesar 60,4\%). Hasil tersebut memang 
terlihat kurang memuaskan, karena kurang dari 70. Hal ini dikarenakan soal penalaran yang diberikan termasuk sulit, atau dikarenakan siswa belum terbiasa dengan soal-soal penalaran. Namun, meskipun demikian, jika mengacu kriteria yang telah ditetapkan pada Tabel 2, game edukasi "MENALAR" dapat dikatakan Efektif.

Penggunaan game edukasi juga dapat membangkitkan keinginan dan minat yang baru, membangkitkan motivasi dan rangsangan kegiatan belajar (Hung, Huang, \& Hwang, 2014), membantu meningkatkan pemahaman, serta menyajikan materi secara menarik dan terpercaya (Arsyad, 2011). Selain itu, posisi media pembelajaran berbasis game juga sebagai sumber belajar mandiri, yang tidak hanya dapat digunakan sebagai alat bantu pembelajaran, tetapi juga dapat digunakan siswa dengan atau tanpa guru mata pelajaran yang bersangkutan (Sari, Saputro, \& Hastuti, 2014).

Beberapa kajian penelitian juga menunjukkan dampak positif dari pemanfaatan game edukasi atau edugame dalam pembelajaran, khususnya pada matematika. Dengan bantuan game edukasi yang dikembangkan, diharapkan dapat meningkatkan kemampuan berpikir siswa, sebagaimana sejalan dengan hasil penelitian dari Aini, Ayu, \& Siswati (2019). Selain itu, salah satu tujuan pengembangan game edukasi "MENALAR" adalah mendorong siswa untuk aktif berpartisipasi dalam memecahkan masalah yang diberikan dan berpikir kritis terhadap permasalahan yang tertuang di dalam game tersebut. Hal ini sejalan dengan hasil penelitian Rasyid, Gaffar, \& Utari (2020).

Secara keseluruhan, menurut para validator, game edukasi "MENALAR" yang dikembangkan memiliki beberapa keunggulan. Penggunaan game edukasi "MENALAR" dapat menjadi alternatif untuk pembelajaran jarak jauh, pembelajaran yang mandiri, menambah motivasi siswa untuk belajar sambil bermain, meskipun ternyata hasil belajar yang diperoleh belum menunjukkan skor di atas 80 . Selanjutnya, karena sifat dari aplikasi ponsel cerdas yang dapat digunakan kapan saja dan di mana saja, media pembelajaran berbentuk aplikasi seperti ini dapat dimainkan sewaktu-waktu sehingga dalam penggunaanya media dikatakan sangat praktis. Selain itu, media pembelajaran ini juga dikemas secara jelas, pewarnaannya menarik, tombol juga berfungsi dengan baik, serta diiringi dengan backsound yang menggembirakan agar dapat membangun motivasi siswa, sehingga siswa tertarik dalam mengikuti pembelajaran matematika, khususnya mengenai soal-soal penalaran. Namun, sejauh ini, game edukasi "MENALAR" juga mempunyai keterbatasan, diantaranya belum dapat dimainkan secara online, soal penalaran yang diberikan sebanyak 15 saja, hanya dapat dijalankan di ponsel cerdas dengan sistem operasi Android, dan belum belum sampai tahapan distribusi ke Google Play Store dikarenakan peninjauan yang lebih lama.

\section{KESIMPULAN DAN SARAN}

Berdasarkan hasil penelitian dan pengembangan yang dilakukan, maka dapat disimpulkan bahwa Game Edukasi "MENALAR" berbasis Adobe Animation $C C$ yang telah dikembangkan termasuk dalam kategori sangat valid dengan persentase sebesar $88,9 \%$, sangat praktis dengan persentase sebesar 83,6\%; dan efektif dengan persentase $60,4 \%$. Secara keseluruhan 
game edukasi "MENALAR" yang dikembangkan dapat dikatakan layak dan dapat dijadikan media pembelajaran alternatif dalam kegiatan pembelajaran matematika, khususnya mengenai soalsoal penalaran.

Adapun saran ke depannya adalah dapat dilakukan pengembangan game edukasi serupa yang lebih menarik dan diukur efektivitasnya dengan langkah-langkah statistik $U j i-t$.

\section{DAFTAR PUSTAKA}

Aini, B. O., Ayu, K. C., \& Siswati. (2019). Pengembangan Game Puzzle Sebagai Edugame Berbasis Android Untuk Meningkatkan Kemampuan Berpikir Matematika Siswa SD. Jurnal Teori dan Aplikasi Matematika (JTAM), 3(1), 7479.

Asyhar, R. (2012). Kreatif Mengembangkan Media Pembelajaran. Jakarta : Referensi

Arsyad, A. (2011). Media Pembelajaran. Jakarta : PT. Raja Grafindo Persada

Dasmo, Astuti, I. A., \& Nurullaeli. (2017). Pengembangan Packet Mobile Learning Berbasis Android. JRKPF UAD, 4(2), 7177.

Festus \& Adeyeye. (2012). The Deveopment and Use of Mathematical Games in Schools. Paper of Mathematical Theory and Modelling, 2(8), 10-13.

Hung, C.M., Huang, I., \& Hwang, G.J. (2014). Effects of digital game-based learning on students' self efficacy, motivation, anxiety, and achievements in learning mathematics. J. Comput. Educ, 1(2-3), 151-166.

Ismanto, E., Novalia, M., \& Herlandy, P. B. (2017). Pemanfaatan Smartphone Android sebagai Media Pembelajaran bagi Guru SMA Negeri 2 Kota Pekanbaru. Jurnal untuk Mu negeri, 1(1), 42-47.

Kuswanto, J., \& Radiansah, F. (2018). Media Pembelajaran Berbasis Android pada Mata Pelajaran Sistem Operasi Jaringan Kelas XI. Jurnal Media Infotama, 14(1), 15-20.

Larasati, D., Pratama, R.A., \& Khotimah, H. (2019). Pengembangan Media Pembelajaran TORIQ (Vector Intelligence Quiz) Berbasis Android pada Siswa Kelas X SMK Kesehatan Airlangga Balikpapan Tahun Ajaran 2018/2019. Skripsi: Universitas Balikpapan (Tidak Diterbitkan)

Lubis, I. R., \& Ikhsan, J. (2015). Pengembangan Media Pembelajaran Kimia Berbasis Android untuk Meningkatkan Motivasi Belajar dan Prestasi Kognitif Peserta Didik SMA. Jurnal Inovasi Pendidikan IPA, 1(2), 191-201.

Mikrayanti. (2016). Meningkatkan Kemampuan Penalaran Matematis Melalui Pembelajaran Berbasis Masalah. Suska Journal of Mathematics Education, 2(2), 97-102. 
DOI: https://doi.org/10.24127/ajpm.v9i3.3027

Muhson, A. (2010). Pengembangan Media Pembelajaran Berbasis Teknologi Informasi. Jurnal Pendidikan Akuntansi Indonesia, 8(2), 1-10.

Muyaroah, S., \& Fajartia, M. (2017, November). Pengembangan Media Pembelajaran Berbasis Android dengan menggunakan Aplikasi Adobe Flash CS 6 pada Materi Pelajaran Biologi. Innovative Journal of Curriculum and Educational Technology, 6(2), 79-83.

NCTM. (2000). Principles And Standards For School Mathematics. Reston, VA: NCTM.

Nurajizah, S. (2016). Implementasi Multimedia Development Life Cycle pada Aplikasi Pengenalan Lagu Anak-Anak Berbasis Multimedia. Jurnal Prosisko, 3(2), 14-19.

Panagiotakopoulos. (2011). Appying a Conceptual Mini Games for Supporting Simple Mathematical Calculation Skill : Student's Perceptions and Considerations. World Journal of Education, 1(1), 3-4.

Rasyid, A., Gafar, A.A., \& Utari, W., (2020). Efektivitas Aplikasi Mobile Learning Role Playing Game (RPG) Mover MV untuk Meningkatkan Kemampuan Berpikir Kritis. Jurnal Mangifera Edu, 4(2), 107-115.

Rozak, A., Darmadi, \& Murtafi'ah, W. (2018). Pengembangan Media Pembelajaran Sasa-Aura untuk Meningkatkan Prestasi Peserta
Didik SMK Cendekia Madiun Tahun Ajaran 2017/2018. Jurnal Pendidikan dan Ilmu Pengetahuan, 18(1), 31-50.

Rusman. (2012). Belajar dan Pembelajaran Berbasis Komputer : Mengembangkan Profesionalisme Guru Abad 21. Bandung: Alfabeta

Sanjaya, W. (2012). Perencanaan dan Desain Sistem Pembelajaran. Jakarta : Kencana Prenada Media Grup.

Sari, W., Saputro, S., \& Hastuti, B. (2014). Pengembangan Game Edukasi Kimia Berbasis Role Playing Game (RPG) pada Materi Struktur Atom sebagai Media Pembelajaran Mandiri untuk Siswa Kelas X SMA di Kabupaten Purworejo. Jurnal Pendidikan Kimia (JPK), 3(2), 97-98.

SERIN, O. (2011). The Effects of The Computer Based Instruction on The Achievement and Problem Solving Skills of The Science and Technology Students. The Turkish Online Journal of Educational Technology, 10(1), 183-201.

Setiawan, T. H. (2018). Efektivitas Media Pembelajaran Terhadap Penalaran dan Komunikasi Matematika Siswa. Jurnal Saintika Unpam, 1(1), 56-73.

Shadiq, Fadjar, (2004). Penalaran, Pemecahan Masalah dan Komunikasi dalam Pembelajaran Matematika. PPPG Matematika Yogyakarta. 
DOI: https://doi.org/10.24127/ajpm.v9i3.3027

Sholihah, D. A., \& Mahmudi, A. (2015). Keefektifan Experiential Learning Pembelajaran Matematika Materi Bangun Ruang Sisi Datar. Jurnal Riset Pendidikan Matematika, 2(2), 175-185.

Siregar, N. R. (2017). Persepsi siswa pada pelajaran matematika: studi pendahuluan pada siswa yang menyenangi game. Prosiding Temu Ilmiah X Ikatan Psikologi Perkembangan Indonesia, 1, 224-232.

Somatanaya, Gde A. (2017). Analisis Kemampuan Berpikir Nalar Matematis Serta Kontribusinya Terhadap Prestasi Belajar Mahasiswa. Jurnal Teori dan Riset Matematika, 1(2), 55-62.

Sugiyono. (2017). Metode Penelitian Pendidikan. Bandung: Alfabeta.

Suprianto, A., Ahmadi, F., \& Suminar, T. (2019). The Development of Mathematics Mobile Learning Media to Improve Students' Autonomous and Learning Outcomes. Journal of Primary Education, 8(1), 84-91.
Sutopo, H. (2009). Pengembangan Model Pembelajaran Pembuatan Aplikasi Multimedia Khususnya Puzzle Game pada Mata Kuliah Multimedia. Jakarta: Universitas Negeri Jakarta.

Wibawanto, W. (2017). Membuat Bermacam Game Android dengan Adobe Animate. Yogyakarta: Penerbit ANDI .

Yektyastuti, R., \& Ikhsan, J. (2016). Pengembangan Media Pembelajaran Berbasis Android pada Materi Kelarutan untuk Meningkatkan Performa Akademik Peserta Didik SMA. Jurnal Inovasi Pendidikan IPA, 2(1), 88-99.

Yuliana, R. (2017). Pengembangan perangkat pembelajaran dengan pendekatan PMRI pada Materi Bangun Ruang Sisi Lengkung untuk SMP Kelas IX. Jurnal Pendidikan Matematika, 6(1), 60-67. 